\title{
Globalization and the Quest for Governance
}

\author{
Review By Wil Hout \\ Department of Political Science, University of Nijmegen, the Netherlands
}

Globalization: Critical Reflections. Edited by James H. Mittelman. International Political Economy Yearbook, Volume 9. Boulder and London: Lynne Rienner, 1996. 273 pp., \$49.95 (ISBN: 1-55587-565-3).

Globalization in Question: The International Economy and the Possibilities of Governance. By Paul Hirst and Grahame Thompson. Cambridge: Polity Press, 1996. 227 pp., $\$ 54.95$ cloth (ISBN: 0-7456-1244-X), \$21.95 paper (ISBN 0-7456-1245-8).

Regionalism and World Order. Edited by Andrew Gamble and Anthony Payne. New York: St. Martin's Press, 1996. 282 pp., \$55.00 cloth (ISBN: 0-312-15987-0), \$19.95 paper (ISBN: 0-312-15988-9).

The literature on globalization, and on possible ways to counter this trend, has unmistakably boomed ever since the end of the Cold War revolutionized international political and economic relations. Many accounts of the causes and consequences of globalization evoke reminiscences of the writings on interdependence that were produced some fifteen to twenty years ago (Jones 1995). Unfortunately, contemporary accounts of globalization share some of the main weaknesses of the interdependence literature, such as the absence of clearly defined concepts, imprecision about causal effects and consequences, and mystifications concerning the overall significance of the phenomenon for international political and economic relations. Moreover, much of the literature on globalization is highly ideological.

To date, the discourse on globalization in policymaking circles and in the media appears to be predominantly positive. Influential liberal-functionalist interpretations predict the end of the nation-state as the prime unit of political organization. As Kenichi Ohmae (1995:4) puts it:

\begin{abstract}
Taken together, the mobility of these four I's [investment, industry, information technologies, and individual consumers] makes it possible for viable economic units in any part of the world to pull in whatever is needed for development. They need not look for assistance only to pools of resources close to home. Nor need they rely on the formal efforts of governments to attract resources from elsewhere and funnel them to the ultimate users. This makes the traditional "middleman" function of nation states-and of their governments-largely unnecessary.
\end{abstract}

These overly positive interpretations of globalization seem to be among the main impulses for new and more critical interpretations of the phenomenon. All three of the books reviewed here share this critical outlook. According to James 
Mittelman, in his introduction to Globalization: Critical Reflections, "Globalization sets in train conflicts among competing capitalisms, generates deeper or reconfigured intraregional disparities, engenders interregional rivalries among neomercantilist coalitions, and has combined with local forces to consign, at the end of this millennium, 265 million people on one continent to poverty, with little hope for escape in sight” (p. 18). By contrast, Paul Hirst and Grahame Thompson question the claims of "radical globalists," such as Ohmae, that the international economy is globalized. Moreover, they argue that those praising globalization misconstrue the alternatives, arguing that "The opposite of a globalized economy is . . . not a nationally inward-looking one, but an open world market based on trading nations and regulated to a greater or lesser degree both by the public policies of nation states and by supra-national agencies" (p. 16). Thus, in Globalization in Question Hirst and Thompson set up a research agenda that focuses on governance of the international economy, an approach that differs fundamentally from that advocated by globalists. Finally, Regionalism and World Order, a collection of essays written by scholars from the University of Sheffield and edited by Andrew Gamble and Anthony Payne, focuses on the "new regionalism" that has become a central feature of the international political economy during the last decade. Regionalism is seen in the context of the purported tendency toward globalization. More precisely, it is perceived as one way for politicians to "respond to the structural power of international capital, which demands the continuing openness of the world economy" (p. 16). Gamble and Payne's research agenda converges with that proposed by Hirst and Thompson; both books focus on alternative means for governing the contemporary international economy.

Mittelman's Globalization: Critical Reflections-the 1996 International Political Economy Yearbook-contains nine "critical reflections" on globalization, along with an introductory and concluding chapter by the editor. As separate pieces of scholarship, all the contributions are worth reading, but, apart from the common focus on globalization, very little ties the chapters together. Mittelman has formulated several questions-about the causes and mechanisms of globalization, the possibilities for transformation, and the right analytical focus for studying globalization-and has asked each of the contributors "to use my introductory series of questions and analytical propositions as a target to attack and a springboard for their own studies" (p. 2). He also provides a generic definition of globalization, noting that "driven by changing modes of competition, globalization compresses the time and space aspects of social relations. In short, globalization is a market-induced, not a policy-led process" (p. 3). Yet, the programmatic focus or "avenue of inquiry" that he outlines (p. 3) leaves the individual authors with too much latitude. As a result, the chapters differ substantially with respect to the theoretical approach, research method, and analytical level.

In what is euphemistically titled "A Perspective on Globalization," Robert W. Cox extends his analysis of the state-society complex, laid out in Production, Power, and World Order (Cox 1987), to the present era. Cox sees globalization as a new phase in the post-World War II order, following upon the crisis of the 1970s (p. 23). He takes globalization, at least in part, to be an ideological instrument used by "multinational corporations and banks, principal agents of globalization" who represent themselves as "primary agents of economic development" (p. 23). In his view, globalization is dominated by three contradictions: social polarization within and among societies, the loss of regulatory power by states, and the tendency toward decomposition of civil society (pp. 26-27).

The globalization literature's frequent emphasis on the dominance of capital and the reduced role of the state can obscure the fact that many politicians, under the influence of supply-side economics, have stressed the benefits of the "unregu- 
lated" market and discarded several instruments of economic management. Fortunately, some of the contributors to Globalization: Critical Reflections pay more attention to the role of the state. For instance, Saskia Sassen ("The Spatial Organization of Information Industries") emphasizes that deregulation has been a main element in reducing the regulatory capacity of the state (p. 42). In her view, the regulation gap has been filled, in part, by the private sector, which has created its own regulatory mechanisms - such as international commercial arbitration and security or bond rating agencies (p. 46). Likewise, Leo Panitch ("Rethinking the Role of the State") draws on earlier neo-Marxist theorizing to argue that states have been "the authors of a regime that defines and guarantees, through international treaties with constitutional effect, the global and domestic rights of capital" (p. 85).

One of the key goals of Globalization: Critical Reflections is to provide insight into the countermovements to globalization-a topic dealt with primarily in the chapters making up Part 2 of the volume: The Counterthrust to Globalization: Political and Cultural Resistance. Thus, Glenn Adler argues that in South Africa labor has been "a source of counterhegemonic ideas for industrial development, economic reconstruction, and political democratization" (p. 124). In another chapter, June Nash and Christine Kovic analyze the 1994 revolt in southern Mexico. According to Nash and Kovic, this revolt involved the rejection of President Carlos Salinas's attempt to use the North American Free Trade Agreement "to integrate Mexico into the global economy by promoting private enterprise in both the agricultural and industrial sectors" (p. 167). Finally, Mustapha Kamal Pasha and Ahmed I. Samatar focus on the resurgence of Islam as "an alternative construction of modernity, cognizant of nonmaterialist dimensions of progress and their place in an ethical (Islamic) social formation" (p. 191). In their view, "Islamic piety" is not identical to fundamentalism; rather, it contains ideas about the best social and political order, about the meaning of materialism, and about modernity. Although the relationship between globalization and the rise of these resistance movements is sometimes tenuous and usually implied rather than demonstrated, these chapters do address a coherent set of questions.

In addition, several authors try to formulate a political program to "democratize" globalization. According to Mittelman "there is a clash emerging between two models: neoliberal globalization, which at present is the dominant force, and democratic globalization, a far less coherent counterforce” (pp. 240-241). These authors make clear, however, that democratization is not an unproblematic alternative. For example, Fantu Cheru ("New Social Movements: Democratic Struggles and Human Rights in Africa") argues that the pressure for democratization in many African countries was directly linked to the expectation that standards of living would rise. In Cheru's view, the failure of the new, so-called democratic regimes to deliver wealth, better education, housing, and health care is "undermining the process of democratic transitions" (pp. 154-155). Furthermore, as Stephen Gill ("Globalization, Democratization, and the Politics of Indifference") argues, to counter the unequalizing and conflictive tendencies inherent in globalization a "double democratization," at both local and global levels, is necessary (p. 205). Although Gill's argument sounds appealing, many pleas to extend the principles of democratic rule beyond the level of the nation-state have failed because of the resistance of the powerful. There is little reason to expect that this resistance will be less in this case.

In contrast to the Mittelman volume, Paul Hirst and Grahame Thompson start Globalization in Question "with a mixture of scepticism about global economic processes and optimism about the possibilities of control of the international economy and of the viability of national political strategies" (p. 1). Key to their argument is the juxtaposition of two models or ideal types of the international economy: 
A globalized economy is an ideal type distinct from that of the inter-national economy
and can be developed by contrast with it. In such a global system distinct national
economies are subsumed and rearticulated into the system by international processes
and transactions. The inter-national economy, on the contrary, is one in which
processes that are determined at the level of national economies still dominate and
international phenomena are outcomes that emerge from the distinct and differen-
tial performance of the national economies. The inter-national economy is an
aggregate of nationally located functions. (p. 10)

Hirst and Thompson's distinction between globalization and internationalization highlights issues that are often overlooked in the literature on globalization, such as the "fundamental problematicity" of governing global processes, and the possible limits to the political influence and economic bargaining power of organized labor (pp. 10-13). At the same time, the distinction presents a problem that is inherent in ideal types: even though the categories may be legitimate theoretically, it can be difficult to determine empirically where one ends and the other begins. The authors acknowledge this problem (p. 15); they even go as far as to indicate that "in certain conditions the globalized economy would encompass and subsume the inter-national economy. The globalized economy would rearticulate many of the features of the inter-national economy, transforming them as it reinforced them" (p. 16, italics in the original). Yet, Hirst and Thompson conceptualize globalization in such extreme terms that it seems unlikely that the present-day international order can be understood as a globalized economy. As a result, readers who do not share Hirst and Thompson's interpretation of the facts presented may argue that Globalization in Question is based on circular reasoning.

Because of the wealth of empirical material presented, Globalization in Question is a very useful book. Hirst and Thompson begin with an analysis of the history of economic internationalization and the degree to which contemporary processes are unique. They conclude that "the level of integration, interdependence, openness, or however one wishes to describe it, of national economies in the present era is not unprecedented. Indeed, the level of autonomy under the gold standard up to the First World War was much less for the advanced economies than it is today" (p. 49). Moreover, the levels of trade and investment flows, expressed in terms of nations' gross domestic product, and the degree of international migration were also higher before 1914 than at present (p. 31). Thus, they argue that the gold standard represented the "quintessential integrated economy," requiring a degree of policy coordination among monetary authorities that left governments little room for independent policy making (pp. 44-45).

Turning to the contemporary international economy, Hirst and Thompson issue a forceful attack on the "radical globalist" position. They point out that the highly unequal nature of the international economy contrasts sharply with radical assumptions. In their judgment, the international economy is oligopolistic, with strategic alliances characterizing relations among multinational companies; it is not the "single open competitive market" (p. 53) propounded by globalists. Moreover, trade and investment in the contemporary economy are highly concentrated in the "Triad": North America, the European Economic Area, and Japan. In so far as investments to non-Triad countries are important, "relatively isolated clusters of main actor and client states are emerging, which are geographically discrete and stabilizing" (p. 64). Thus, the research presented in Globalization in Question indicates the continued existence of vertically, rather than horizontally integrated investment linkages. As to the nature of internationally operating firms, Hirst and Thompson conclude that "the home-oriented nature of MNC activity along all the dimensions looked at [distribution of sales, assets, subsidiaries and affiliates, and profits] seems overwhelming" (p. 95). 
In this light, Hirst and Thompson are not optimistic about the prospects for developing economies. In their view, the globalist expectation that spreading economic activity will radically improve the plight of developing countries has low plausibility. They argue that the success of such "dynamic Asian economies" as Singapore, Hong Kong, South Korea, and Taiwan has resulted as much from "highly particular circumstances" (p. 106), such as the overall size of the country and the relative size of agriculture, as from "determined national economic management and solidaristic public policies" (p. 115). On the whole, Hirst and Thompson conclude that the "results of Asian growth are . . . unspectacular" (p. 112 ) if the mobilization of labor and capital is taken into account. High population growth, backward agrarian sectors, and reduced opportunities for protectionism and inward-looking policies because of the new trade regime will make it hard for developing countries to copy the Asian model. As a result, according to Hirst and Thompson, the present dominance of the advanced countries will continue and most developing countries will remain comparatively poor (p. 120).

Given this critique of globalization, what is the future of governance of the international economy? Because the "emerging trading blocs" are locked in a "reciprocal relationship" (p. 124-125), an outright return to protectionism is very unlikely. Rather, Hirst and Thompson expect that "a minimal modified-multilateral international governance structure will prevail in the immediate future" (p. 129). This will be a trilateral regime based on the three main blocs and supported by a system of "minilateralism": "bilateral negotiations that are emerging between the three main players on important issues, and between them and other minor parties" (p. 129). The main issues will be the maintenance of the international financial regime, trade relations, investment and labor migration, economic development, and economic transition (pp. 129-140). Although the economic role of national governments is severely limited, they "can still compensate for the effects of internationalization and for the continued volatility of the financial markets" (p. 144). The main instruments of national economic governance will be fiscal, tax, and energy policies.

In a separate chapter on "The European Union as a Trade Bloc," Hirst and Thompson analyze "the most ambitious project of multinational economic governance in the modern world" (p. 153). In their view, the European Union (EU) should be willing to take up economic governance for the European continent as a whole because there is a "need for policies that link the rich and poor regions in the EU, and that link the rich states of the EU with the poor ones of Eastern Europe in a common search for prosperity" (p. 169). By pursuing a "continental Keynesianism" (p. 163), the European Union can keep the wealth gap from growing, both in the EU and in Europe, and can thus prevent the intensification of conflicts and the growth of migration.

Finally, Hirst and Thompson consider the future of the nation-state as a locus of governance. This part of the book can be seen as the core of their argument; it is a counterweight against the defeatism of those who argue that globalization has rendered political action ineffective. As Hirst and Thompson incisively note, "This new political rhetoric [of globalization] is based on an anti-political liberalism. Set free from politics, the new globalized economy allows companies and markets to allocate the factors of production to greatest advantage, and without the distortions of state intervention" (p. 176). Yet, markets alone cannot provide the levels of "interconnection and coordination" (p. 184) that are necessary to ensure the functioning of today's complex division of labor. Although they do not quote him, Hirst and Thompson's argument resembles Polanyi's classic comment that the idea of a "self-regulating market" implies a "stark utopia" (Polanyi 1957:3). As an alternative, Globalization in Question presents a brief but trenchant theory of national 
economic governance. According to Hirst and Thompson, national economic systems provide "forms of reassurance to firms against the shocks and the risks of the international economy" (p. 187). Because of the danger of outside disturbance, "markets and companies cannot exist without a public power to protect them" (p. 188). Moreover, as the principal political actors, states are the only entities that can ensure that international bodies are responsive to "the world's key publics" (p. 191).

In contrast to Hirst and Thompson, the contributors to Regionalism and World Order, edited by Andrew Gamble and Anthony Payne, do not question the purported trend toward globalization. As the editors argue in their introduction, the 1970s and 1980s have been characterized by the development of "a genuine global economy, grounded in production and finance, ... replacing the former Bretton Woods international economy premised upon exchange relations between national economies" (p. 15). Yet, Gamble and Payne are equally uncomfortable with globalization and seek "to assess the origins, significance and likely evolution of the trend towards regionalism" as a counterforce to it (p. 1).

Gamble and Payne propose that the "new international political economy (IPE)" can best help us understand the related issues of regionalism, globalization, and hegemony. In their view, mainstream theories, in particular neorealism and neoliberalism, have converged toward "a discourse constructed around a particular view of the hegemonic state" (p. 4). The new IPE, inspired heavily by Robert Cox's views of ideological hegemony, is comprised of "a loose college of scholars and a diverse range of approaches," including neostructuralism, world-system theory, institutionalist economics, the French regulation school, scholars from the developing world, and neo-Gramscian approaches (p. 9).

Gamble, Payne, and their coauthors stress the type of ideological hegemony that resulted in the Pax Americana, which dominated the international economic order after World War II. In this view, U.S. hegemony has been in decline since the 1970 s, and "the formative aspect of the new global political system is seen to be the structural power of internationally mobile capital" (p. 15). State strategies are reduced to "the adjustment of national political practices to the exigencies of the global economy" (p. 16). According to Gamble and Payne, nearly all states try to "ride two tigers simultaneously": they try to respond to international capital, which requires openness to the world economy, and to serve national interests, which demand competition for relative national advantages (p. 16). The research questions of Regionalism and World Order focus on (1) the extent to which states have responded to the decline of U.S. hegemony by way of regionalism, and (2) what sort of regionalist projects are emerging (p. 17).

Despite Gamble and Payne's attempt to devise a common framework for the volume, the theoretical discussion remains detached from the six empirical chapters. This feature becomes clear in the conclusion, in which the editors acknowledge that important differences exist among the "regionalist projects": "Although regionalist projects have certain assumptions in common and have been framed within a common globalist perspective, they are also quite different from one another. This diversity reflects the different historical structures which exist within each region, as well as the uneven impact of globalisation" (p. 253). The editors mention world-system theory as an element of the new IPE, but the theoretical framework would have been more satisfactory, and the conclusion less ad hoc, if Gamble and Payne had incorporated some of this theory's insights about the differentiation of the international political-economic order. Gamble and Payne would also have benefited from ideas about "uneven globalization" (Holm and Sørensen 1995) in accounting for differences among regions in their explanatory model. 
Despite these theoretical shortcomings, Regionalism and World Order should have a profound impact on theorizing about regionalism. A major benefit of the volume is its broad conception of regionalism itself. Many books on the subject restrict themselves to formal regional arrangements, such as the North American Free Trade Area, the European Union, the Association of South East Asian Nations, Mercosur, and the like. Gamble, Payne, and their coauthors also look at informal processes of regionalism, as in East Asia, and at hybrid regionalisms taking shape between developed and developing countries. Moreover, the contributors to $R e^{-}$ gionalism and World Order acknowledge that "regions" are not natural, primordial entities. Rather, they are social constructions whose delineations are subject to political and often ideological struggles.

Along with an introduction and conclusion, Regionalism and World Order contains six well-informed and highly readable case studies. The case studies are grouped into three categories (regionalism in Europe, the Americas, and Asia) and are written by regional specialists at the University of Sheffield (United Kingdom).

Chapters written by Stephen George and Ian Kearns focus on Western and Eastern Europe respectively. George assesses the creation of the internal market (with free flows of goods, services, labor, and capital) under the Europe 1992 project, concluding that an important difference exists between the "free trade" position of Great Britain and the "strategic trade" view of France. Support from the "largest industrial concerns in Europe, which were not only European but global players" (p. 36), proved crucial to the success of the 1992 project. In George's view, Germany's post-unification policy, aimed at tying the country into the EU, proved to be crucial for progress toward further integration. In his analysis of Eastern Europe, Kearns focuses on the "major relocation of the region," which is clearly geared to a "return to the West" (p. 87). In his view, the key to saving the post-Cold War transformation of Eastern Europe lies outside the region, linked as it is to improved trading relations, increased aid, and more flexibility in Russian foreign policy.

Chapters by Anthony Payne and Jean Grugel deal with inter-American relations. They are complementary because they start from the same assumption: that the relations between the United States and the countries of Latin America and the Caribbean are characterized by "asymmetrical integration" (p. 142). Payne argues that the Enterprise for the Americas initiative, proposed by the Bush administration and supported by President Bill Clinton, aims at creating "an increasingly integrated hemispheric economy which the US could then use as the base from which to export ever more competitively to other, more distant, markets" (p. 107). Jean Grugel discusses reactions to such ideas in Latin America and the Caribbean. She emphasizes that the debt crisis of the 1980s brought about a "total crisis of confidence" in the region (p. 137), which resulted in "a reordering of hegemony in the wake of the break-up of the previous model of inter-American politics and the collapse of the search for autonomous [Latin American and Caribbean] strategies for development" (p. 139). "Hemispheric free trade" was greeted with enthusiasm in the region as a way to benefit from the asymmetrical relations with the United States. Under U.S. influence, free trade gradually transformed into a "hub and spoke" pattern with the United States as the hub (p. 148). Governments in Latin America and the Caribbean perceive their options for development as either "successful liberalization or unsuccessful liberalization," without any viable alternatives (p. 163).

Finally, Glenn Hook and Ngai-Ling Sum discuss the meaning of regionalism in the context of East Asia. Hook focuses on the role of Japan in East Asia and stresses that its position has to be analyzed in conjunction with the Asian security policy of the United States. Despite Japan's slightly more active military policy, Hook argues 
that the United States remains central to the security regime of the Asia-Pacific region and continues to be an important market for the products of the region. Because of U.S. dominance, the countries in the region, including Japan, do not venture into types of regionalism that are opposed by the United States (p. 200). Ngai-Ling Sum focuses on four main identities proposed for the region. The first concerns the position of the United States and converges with Hook's emphasis of an Asia-Pacific identity. Japan, according to Sum, has looked more to its own economic interests, as it "has been co-ordinating and reconstructing the region to enhance its own geoeconomic advantages" (p. 225). China has emphasized a form of subregionalism, related to ideas about a "Greater China" that included Taiwan, Hong Kong, and Macau. In this perspective, the overseas Chinese serve as investors who can take advantage of low wages in southern China. Finally, the construction of subregionalism as it is supported by newly industrializing countries such as Singapore focuses on the creation of "growth triangles," forging a link between more and less developed parts of the region in order to combine cheap labor, abundant reserves of raw materials, and capital to set up new production sites.

Despite the fact that the three books reviewed here take quite disparate positions regarding the nature and effects of "globalization," the editors and authors of all three are similarly engaged in what can be called the quest for global governance. This quest is a scholarly one, but it is also politically motivated. It expresses both the empirical disbelief that we are witnessing the demise of the state as a political actor and the normative reluctance to side with those ideologues who praise the victory of the market as a form of governance. Scholars and students of contemporary international relations who welcome this quest for global governance will enjoy and benefit from these books because they show that contemporary social science has something to offer, both in terms of civil responsibility and scholarly imagination.

\section{References}

Cox, Robert W. (1987) Production, Power, and World Order: Social Forces in the Making of History. New York: Columbia University Press.

Holm, Hans-Henrik, and Georg Sørensen, eds. (1995) Whose World Order? Uneven Globalization and the End of the Cold War. Boulder: Westview Press.

JonEs, R. J. BARRY. (1995) Globalisation and Interdependence in the International Political Economy: Rhetoric and Reality. London and New York: Pinter.

Ohmae, Kenichi. (1995) The End of the Nation State: The Rise of Regional Economies. New York: Free Press. Polanyi, KarL, ED. (1957) Trade and Market in the Early Empires: Economies in History and Theory. Glencoe, IL: Free Press. 